\title{
FACTORS AFFECTING SUBSISTENCE FARMING IN RURAL AREAS OF NYANDENI LOCAL MUNICIPALITY IN THE EASTERN CAPE PROVINCE
}

\author{
Siphesihle, Q. ${ }^{1}$ and Lelethu, M. ${ }^{2}$
}

Corresponding Author: Qange S. Email: siphesihleqange@gmail.com

\begin{abstract}
Agriculture is the foremost locomotive of the economic growth for Sub-Saharan African countries, especially South Africa. Subsistence agriculture is one of the imperative segments in the South African economy and it remains a substantial sector for livelihood generation. Agricultural activities have an ability to provide nutrition, economic, social status and reduce rural poverty. However, subsistence farming has experience significant declined over the past 10 years due to climate change, scarcity of resources, lack of farming equipment and lack of extension services. Therefore, this paper seeks to examine factors affecting subsistence farming in rural homesteads of Nyandeni Local Municipality. Purposively, the data was collected from 120 households. To examine the factors affecting subsistence production, multiple regression was run. Study results reveal that the majority of the farming households are male-headed with an average age of 60 years with a household size of 6 people in the households. The study reveals that age, gender, and employment have an adverse influence subsistence farming production while education, extension services, household size, farming experience, and income have a positive relationship with subsistence farming. Thus, the study recommends government empowerment and training services that will increase the number of women and youth participating in farming. Further to that, government must promote sustainable food production by ensuring collaboration of all stakeholders in government, private sector and NGOs or CBOs.
\end{abstract}

Key words: Agricultural productivity, Subsistence farming, Poverty.

\section{INTRODUCTION}

Agriculture has a momentous role in contributing to rural economic growth and ensuring food security (Masuku, Selepe \& Ngcobo, 2017). In Africa, the majority of rural households generates their livelihoods from agriculture and agricultural related activities (Poulsen, Mcnab, Clayton, \& Neff, 2015). Subsistence agriculture plays a fundamental role in the provision of better living and food security in evolving of rural communities (Department of Agriculture, Forestry \& Fisheries, 2016). Mashamaite (2014) stipulated that subsistence agriculture deliver food security to rural families by decreasing food prices through improved food supply, creating employment prospects for the poor, enlightening family income and providing food for family ingesting. Baiphethi \& Jacobs (2009) designate that subsistence agriculture accounts for over $90 \%$ of the food supply in most emerging republics. Heger, Zens \& Bangalor (2018) highlighted that about $60 \%$ of Africa's population is dependent on agricultural activities. In

\footnotetext{
${ }^{1} \mathrm{MSc}$ Student at the University of Fort Hare: Department of Agricultural Economics and Extension. University of Fort Hare, P/Bag X1314, Alice, 5700; E-mail: siphesihleqange@ gmail.com

2 Dr. L. Mdoda. Lecturer and Researcher: Agricultural Economics and Extension, University of Fort Hare. University of Fort Hare, P/Bag X1314, Alice, 5700. Tel: 0406022431; E-mail: lelethu.mdoda@gmail.com/ lmdoda@ufh.ac.za, ORCID: 0000-0002-5402-1304
} 
rural areas, farming plays a vital role especially when it comes to income generation. Moreover, agriculture is the most contributing sector to the GDP of the economy in many countries, as compared to other sectors; in both developed and developing countries (Sertoglu, Ugural \& Bekun, 2017; Mehrara \& Baghbanpour, 2016).

According to Mugambiwa \& Tirivangasi (2017) and Dwesini (2015), agricultural production is more important in rural areas of South Africa as it alleviates poverty and creates more job opportunities. Kibirige \& Obi (2015) stated that about 4.75 million South Africans are employed in the agricultural sector, however, majority of them are engaged in subsistence farming. Nethengwe, Uhunamure, \& Tinarwo, (2018) and the agricultural sector in South Africa contributes about $10 \%$ of formal employment, contributing around $2.6 \%$ of GDP. Household farming method or subsistence farming is mostly practiced in rural areas because it is cost effective as compared to large-scale farming (Tibesigwa \& Visser, 2016). Tibesigwa \& Visser (2016), declared that in Africa, about $20.7 \%$ of families are tangled in agriculture while $65 \%$ of these families are involved in agriculture decently for subsistence devotions to meet family food ultimatum. Subsistence farming is more viable in rural areas because it is cheaper and less labour intensive. Subsistence production utilizes family labour because it is family based production and they only sell surplus (World Bank, 2018; Sibhatu \& Quim, 2017). Moreover, production inputs that are required in subsistence farming could be bought from local markets because they are produced locally. Subsistence farming does not need much of educational knowledge; it can be practiced using indigenous knowledge (Mathebula, Molokomme, Jonas \& Nhemachena, 2017, Aliber \& Hart, 2012).

Farming, especially subsistence farming, is declining at an increasing rate in South Africa. Many rural households in Eastern Cape about 78\%, generate their income and livelihoods from subsistence farming (Bedemo, Getnet, Kassa, \& Chaurasia, 2013). However, stated that most rural households' income is generated from other sources such grants, migrant labour and selling of goods rather than agricultural activities, hence the decrease in the subsistence farming. Many factors are stated to be influencing subsistence farming. It has been found rural households have land but lack the motivation to practice farming due to limited access to inputs and poor infrastructure hence their farming is inefficient and decreasing (Mathebula et al., 2017). Subsequently, poverty is dominant in rural areas than it is on a national level, moreover, Mtero (2017) added that rural households have recognised other various sources of livelihoods rather than farming. Other sources include, the renting of animals for traction, sale of labour and off-farm full-time and seasonal employment, hence rural households have a tendency to purchase even vegetables that they have potential to produce (Sibhatu and Qaim 2018). This implies that rural households are no longer investing more in subsistence farming. Therefore, this raises a concern in a significant change in rural livelihoods and what means can be done to overcome this situation because it results to more poverty and food insecurity in rural areas. For instance, in rural areas, decline in subsistence farming is attributed with longer dry spells of drought, inadequate water and nutrient availability, tainted soils and unproductive farming methods (Myeni, Moeletsi, Thavhana, Randela, \& Mokoena, 2019). Consequently, poverty is more prevalent in rural areas than urban areas as subsistence farmers and households still living below the poverty line in rural areas (Khapayi \& Celliers, 2016). Additionally, subsistence farmers lack availability and accessibility on infrastructure which are necessary for farming (Mazibuko \& Antwi, 2019). 
Agricultural production in Eastern Cape, especially in Nyandeni is predominantly depends on rain fed agriculture and less resource base for food production which leads to low productivity (You et al., 2010). Nkonya, Gerber \& Baumgartner (2012) postulated that land degradation is another problem which rural dwellers are faced with as the World is losing one-third of the top soil land faster than new soil is forming, this is adversely affecting food production of the poor people. These problems have intensified due to climate change and the vulnerability of the country, especially those farming households whose means have never been comfortable in the best of times, will be even more prominent. In the province, extreme weather events like droughts and floods, gradual increases in temperatures and increased variability in annual rainfall appear to be common as result of climate change. These changes are seemingly having a damaging effect on the rural poor (Myeni et al., 2019). Dealing with these issues will remain major concerns. But the precise nature of the vulnerability of the rural communities to these problems has not been systematically studied in recent years. The yield level of major crops has declined or remained the same and is failing to meet the population growth rate and decline in own food production. However, the depletion and degradation of land and water pose serious challenges to producing enough agricultural products to meet the growing demand brought by rising population (Ndabeni, 2016). This means food production has to improve using the same or fewer natural resources.

The decline in subsistence production is mainly due to many factors such as institutional and technical factors. However, farming under the subsistence farming is characterised by low levels of production technology and small-sized farm with production largely for subsistence purposes, leaving little marketable surplus (Govendor, Pillay, Siwela, Modi \& Mabhaudhi, 2016). The decline is mainly due to lack of supportive organizations that represent (such as Extension services), serve them and their infrastructure is poorly developed. In addition, access to affordable credit is one of the most important factor affecting production and therefore income of the farming households. The study, therefore, contains an ongoing tendency in rural areas where subsistence farming is low or decreasing. Rural households tend to purchase food from the markets than they would produce for themselves. Thus, it is necessary to examine factors that influence subsistence farming in rural areas of Nyandeni Local Municipality in the Eastern Cape Province. That will allow evaluating the causes and factors influencing households in subsistence farming and that will assist policymakers in planning strategies that could improve subsistence production in rural areas.

\section{METHODOLOGY}

\subsection{Study area}

The study was steered in Nyandeni Local Municipality (NLM). The NLM is one of the five municipalities which fits to the OR Tambo District Municipality in the Eastern Cape Province of South Africa and assembly up nearly a quarter of its ecological region. Nyandeni Local Municipality is positioned in the Eastern fragment of the Transkei expanse of the Eastern Cape Province. It is adjoined in the north by Mhlontlo, in the south by the Indian Ocean, in the east by Port St Johns, and in the west by King Sabata Dalindyebo. The Nyandeni Local Municipality is a Group B metropolis under OR Tambo District Municipality. Nyandeni Local Municipality entails of the twofold previous authoritative constituencies of Libode and Ngqeleni. The dominated tribe in this region is Mpondos with almost $90 \%$ while the remaining $10 \%$ is the mixture of Whites and Zulu speaking people. The municipality has $2474 \mathrm{~km}^{2}$ with a population 
of 309702 people. The NLM have 61867 households with an average of 5 people in the household.

The NLM is one of the municipalities under the OR Tambo District Municipality with a high unemployment rate, which is not surprising as the Eastern Cape Province has a high unemployment rate and poverty rate as the majority of households are living under the poverty line. Households in NLM are deriving their livelihoods through engaging in farming as the majority of the households are not working and fully practicing agriculture for a living. Households in Nyandeni Local Municipality rely on social securities and farming to keep up their households. The main agricultural activities being practices in NLM are crop, vegetable, and livestock farming as it is customary that households must have one type of farming as a means of providing food and income for the household. NLM has a fertile land which is favorable for all the three types of farming and climate is moderate which encourages farming. The study was done in 6 villages which were practicing subsistence farming.

\subsection{Sampling procedure and sample size}

The study made use of a descriptive research approach. The study made use of stratified sampling to choose smallholder farmers that practice subsistence agriculture in the Municipality. The study made practice of stratifying as the researchers were separating livestock farmers and crop farmers. Purposive sampling and random sampling were used to develop the desired sample size. Purposive sampling was used because it is easier to make generalizations about subsistence agricultural in the study region. Random sampling was then used to select subsistence farmers in the Municipality. The sample size was 120 subsistence farmers from Nyandeni Local Municipality. The selected farmers were practicing both crop and vegetable farming in their land for.

\subsection{Data Collection}

Primary data was collected for this study through face-to-face interviews. Following that, a semi-structured questionnaire was designed by the researchers based on the review from the literature. The semi-structured questionnaire was first pre-tested and was overseen to the interviewees with the help of highly skilled enumerators who speaks the local languages (IsiXhosa) fluently. The final version of the questionnaire was later administered to the farmers' head and in the absence of the head, the oldest member of the farm was chosen. The information on the semi-structured questionnaire includes farmers' demographic features, asset endowments, production and farming information, reasons for practicing subsistence farming, challenges and factors influencing subsistence farming in the study are.

\subsection{Analytical Framework}

After collecting the data, data was entered on Excel. Data cleaning, and management of missing data was also done. The study made use of two analytical software's for analysis which were SPSS version 24 and STATA 14. The study used descriptive statistics and multiple regression analysis. 


\subsection{Multiple regression}

The study made use of multiple linear regression model to examine factors affecting subsistence farming in rural areas of Nyandeni Local Municipality. Saqib, Kuwornu, Panezia \& Ali (2018), Meyer \& Nishimwe-Niyimbanira (2016) stated that as a predictive analysis, the multiple linear regression is used to explain the relationship between one continuous dependent variable and two or more independent variables. The goal is to estimate and model the relationship between the set of hypothesized causal variables to understand their influence over subsistence farming. Explanatory variables that were estimated include gender, age, marital status, educational level, household size, production sold, amount per product sold, access to extension services, member of farm organization and social status. The multiple regression model that was used in this study can be described as follows:

$Y=f\left(x_{1}, x_{2}, x_{3}+\cdots \ldots \ldots+x_{n} \ldots \ldots \ldots \ldots \ldots \ldots \ldots \ldots \ldots \ldots \ldots \ldots \ldots\right.$

The empirical model was specified as in equation (2):

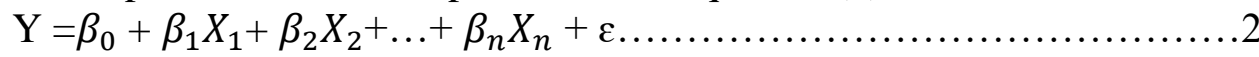

Where:

$\mathrm{Y}=$ dependent variable (Subsistence farming)

$\mathrm{X}_{1}$ to $\mathrm{X}_{\mathrm{n}}=$ independent variables (family size, sex, age, level of education, farm experience, extension service, marital status, source of income, household income and employment status.) $\beta_{0}=$ the value of $Y$ when all of the independent variables are equal to zero

$\beta_{1}$ To $\beta_{n}=$ explanatory coefficients

$\varepsilon=$ the accepted error.

\subsection{Data}

This section represents data which was collected from subsistence farmers in the Nyandeni Local Municipality.

Table 1. Factors affecting own food production

\begin{tabular}{|l|l|l|}
\hline Dependent Variable & Description & $\begin{array}{l}\text { Expected } \\
\text { outcome }\end{array}$ \\
\hline SFRM & Subsistence farming & \\
\hline Explanatory Variable & Description & \\
\hline GEN & Gender of the farming head & - \\
\hline AGE & Age of the farming head & - \\
\hline YFARM & Years of farming & + \\
\hline EXTSERV & Access to extension services & + \\
\hline HHSIZE & Household size & + \\
\hline EDULEV & Education Level & - \\
\hline HINC & Household income & + \\
\hline EMP & Employment status & - \\
\hline SINC & Source of Income & + \\
\hline
\end{tabular}

\section{Gender:}

This refers to the gender of the household head. Most homesteads are headed by females. That may be true because males tend to be migrant labourers in urban area or cities. Women are assumed to be participating more in agricultural activities because they are always taking care of home activities in most cases. 


\section{Age:}

Age is influential especially when it comes to agricultural activities. However, the literature reveals that many individuals that are participating in farming are old people that may be caused by the fact that they grew up farming and that was the only livelihood strategy that is cheaper to them. Therefore, the expected outcome of the study regarding age is that old people are more involved in subsistence farming.

\section{Farming Experience:}

Farming experience gives household an opportunity of conquering poverty. The more the household head has more experience in farming, the more the household will practice subsistence farming.

\section{Family size:}

Family size is essentially the total number of persons residing in one household. The literature reveals that family size tends to influence food consumption in the household. This simply means that large family size results to a high level of food consumption and vice versa. Therefore, it is expected that household with large family size are more involved in subsistence farming with the intent of increasing food availability.

\section{Education level:}

Education determines the literacy rate. People who are educated have diverse ways of acquiring information from various sources. Therefore, it is anticipated that educated people will not participate in subsistence production instead they will invest in off-farm activities.

\section{Household income:}

Household income sometimes can be used to indicate the welfare of the household. Income also determines the monthly household expenditure. Therefore, it is assumed that households with high income will invest their income with non-farm activities. It is anticipated that households that have high income will not practice subsistence farming.

\section{FINDINGS AND DISCUSSION}

\subsection{Socioeconomic characteristics of rural households}

Table 2 shows that the majority of households in the study area were male-headed (60\%) and $40 \%$ female headed. This displays that subsistence farming households were males, which may be credited to the comprehensive labour obligation. The average age of the household heads was 60 years with an average family size of 6 individuals per household. Lilenstein, Woolard, \& Leibbrandt (2018) also discovered that in rural areas, many households are headed by males. The average age of the household head among smallholder irrigators is 60 years. This means that agriculture in the study areas is dominated by elderly people, probably because of mass retrenchments at the mines in the wake of mechanization of mining operations that began in 2010 (Kibirige, 2013). These results may be true because youth has adapted to technology and they migrate to urban areas and cities to find better livelihoods and opportunities (Bhandari \& Ghimire, 2016). The study results revealed that farmers were married with $66 \%$ and that assisted in provision of family labour. The majority of the farming households have primary education, having spent approximately 10 years in school only a handful of respondents did not have any kind of education. This means that subsistence farmers were able to understand 
farming information and market information. Subsistence farmers had a farm size of $2 \mathrm{Ha}$ which they were using to practice crop and vegetable farming.

Table 2. Socioeconomic characteristics of rural households

\begin{tabular}{|c|c|c|c|}
\hline \multicolumn{2}{|l|}{ Variable } & Frequency & Percentage \\
\hline \multirow[t]{2}{*}{ Gender } & Male & 72 & $60 \%$ \\
\hline & Female & 48 & $40 \%$ \\
\hline \multirow[t]{2}{*}{ Extension Service } & Yes & 17 & $14 \%$ \\
\hline & No & 103 & $86 \%$ \\
\hline \multirow[t]{2}{*}{ Employment } & Employed & 46 & $38 \%$ \\
\hline & Unemployed & 74 & $62 \%$ \\
\hline \multirow{5}{*}{ Household income level } & 0-R1 000 & 25 & $21 \%$ \\
\hline & R1 $000-$ R3 000 & 43 & $36 \%$ \\
\hline & R3 000 - R7 000 & 19 & $16 \%$ \\
\hline & \begin{tabular}{|l|} 
R7 000- R10 000 \\
\end{tabular} & 10 & $8 \%$ \\
\hline & $>\mathrm{R} 10000$ & 23 & $19 \%$ \\
\hline \multirow{2}{*}{$\begin{array}{l}\text { Member of the farming } \\
\text { organization }\end{array}$} & Yes & 82 & $68 \%$ \\
\hline & No & 38 & $32 \%$ \\
\hline & & Mean & Standard Deviation \\
\hline \multicolumn{2}{|l|}{ Age } & 60.125 & 1.023 \\
\hline \multicolumn{2}{|l|}{ Household Size } & 6.354 & 2.036 \\
\hline \multicolumn{2}{|l|}{ Years Spent in School } & 9.862 & 0.896 \\
\hline \multicolumn{2}{|l|}{ Farming experience } & 9.023 & 0.023 \\
\hline
\end{tabular}

Family size averaged 6 persons. Farming experienced was 10 years on average while $86 \%$ of farming households revealing they do not have access to any extension services. The study revealed that $68 \%$ of farming households are members of farm organizations and most of these farming households do not work anywhere as their sole occupation is farming as they derive their livelihoods from farming. Most respondents (36\%) earned between ZAR 1001 and ZAR 3,000.00 while $8 \%$ earned above ZAR 7,000-ZAR 10,000.

\subsection{Benefits of subsistence farming in rural area}

Table 2 illustrates benefits of subsistence farming to rural areas of NLM. The study results revealed that the main benefit and reason for subsistence farming was strictly to provide food for home consumption with $66.7 \%$. The results agree with literature that many farmers practice farming to derive livelihood as these results has indicated. Additionally, so, these farmers do not have any form of employment as farming is their solely occupation for living.

Table 2. Benefits of subsistence farming

\begin{tabular}{|l|l|l|}
\hline Benefit of subsistence farming & Frequency & Percentage \% \\
\hline Food provision for home consumption & 80 & 66.7 \\
\hline Income generation & 30 & 25 \\
\hline Employment & 10 & 8.3 \\
\hline
\end{tabular}

The results further depicted that farmers do generate income when they have surpluses with $25 \%$. Lastly, they do employ laborers during harvesting period for assistance in harvesting with 
8.3\%. The results display that subsistence farming had a significant role in rural areas of Nyandeni Local Municipality.

\subsection{Challenges faced by subsistence farmers}

The literature review revealed that subsistence farming in Nyandeni Local Municipality is decline in with several factors. Table 4 below is displaying challenges which are fundamental to the reduction of subsistence farming in the study area. Farmers were choosing more than one challenge they were facing in farming. The principal challenge which challenges subsistence farming in the study area was funding and knowledge with $75 \%$. This is crucial challenge because farmers in the study area had no source of funding which would have assisted them in purchasing modern farming inputs instead of using traditional and obsolete farming technique. The lack of knowledge is contributing to decline of farming as these farmers had only primary education which is just basic education which do not contribute much in farming and which was the reason of using indigenous knowledge for farming. Lack of water availability $(73 \%)$ was another challenge.

This had contributed to decline in subsistence farming due to changing climate which led to prolong dry spells as result of drought, making it very hard for farmers to have water available for farming. The lack of extension services (63\%) was another challenge. This is the main cause because households in the study area they just farm using indigenous knowledge not being assisted. They lack pesticides and herbicides for diseases, lack improved seeds which withstand climate variability and knowledge in terms of farming, such factors contributed vastly to decline in subsistence farming. Lastly, lack of farming equipment is one the challenges that subsistence farmers agreed that it contributed to decline in farming.

Table 4. Challenges faced by subsistence farmers

\begin{tabular}{|l|l|l|}
\hline Challenges faced & Frequency & Percentage \% \\
\hline Finance and Knowledge & 90 & 75 \\
\hline Lack of water availability & 88 & 73 \\
\hline Lack of farming equipment & 70 & 58 \\
\hline Lack of extension services & 76 & 63 \\
\hline
\end{tabular}

\subsection{Factors disturbing subsistence farming in rural areas}

The multiple regression results for factors affecting subsistence farming are presented in Table 5. The dependent variable in the multiple regression was subsistence farming. The explanatory variables were quantified as those related to socioeconomic factors of rural household practicing subsistence farming. For all the variables with a positive coefficient, it implies that as any of them increases, so does Food Production. Table 3 summarizes the empirical results of multiple regression. Based on the results in Table 3, the Pseudo $\mathrm{R}^{2}$ is $70 \%$, and it is an acceptable level, implying that the model's estimates fit the data. And the adjusted $\mathrm{R}^{2}$ is $68 \%$ with a p-value of 0.000 indicating that all the explanatory variables have a significant influence on food production by rural households. The significant level was $5 \%$ and $1 \%$ respectively. The direction of influence of the variable is shown by the signs of the coefficients. A positive sign of the coefficient implies that the particular variable has no influence on the household production and a negative value on the coefficient shows that the particular variable has 
influence on the household production. Table 5 shows the estimated coefficient, standard error and significance value of the variables in the model.

Table 5. Factors affecting subsistence farming in rural areas

\begin{tabular}{|l|l|l|l|}
\hline Variables & Coefficient & Standard Error & Significance value \\
\hline Age & -0.0864 & 10.745 & $0.008 * * *$ \\
\hline Sex & -0.0653 & 1.568 & $0.042 * *$ \\
\hline Family size & 0.0468 & 11.658 & $0.004 * * *$ \\
\hline Educational Level & -0.0856 & 1.748 & $0.049 * *$ \\
\hline Extension Service & -0.0768 & 1.986 & $0.039 * *$ \\
\hline Farm Experience & 0.0487 & 2.563 & $0.019 * *$ \\
\hline Household Income & 0.0529 & 5.988 & $0.009 * * *$ \\
\hline Employment status & -0.0356 & 1.896 & $0.019 * *$ \\
\hline Cons. & 0.985 & 1.756 & 0.561 \\
\hline $\begin{array}{l}\text { Constant }=1.201 \\
\text { R Squared }=0.703 \\
\text { P-value }=0.000\end{array}$ & \multicolumn{3}{|c|}{ LR Chi Square $=56.681$} \\
\hline
\end{tabular}

Note: Asterisks denote the level of significance $* *=5 \%$, while $* * *=1 \%$

The activities in households are controlled by the household head. Age usually influence one's health condition; thus it can be stated that old people are more likely to have health problems. When the household head stops participating in agricultural activities, it is likely that everyone in the household neglect agricultural activities. The results reveal a negative relationship between age and subsistence farming, hence the negative coefficient. From the results, age has a negative coefficient, meaning that age has negative influence on subsistence farming status. That clearly demonstrate that, the more people get older, their participation in agricultural practices decreases. This simply means that old people participate less in agricultural activities. Mashamaite (2014) stated that age influences productivity in agriculture.

Rural households are mostly headed by males (60 per cent). The results reveal a negative relationship that exists between sex and subsistence farming in rural areas. Sex has a negative coefficient and is significant at 1 per cent significance level. This relationship means that maleheaded households are more likely not to produce their own food through subsistence farming. Mathebula et al. (2017) also found that females participate more in agricultural activities and males migrate to cities to look for jobs to look after their families.

There is a positive relationship that exists between family size and subsistence farming production. Family size is significant at 1 per cent significance level. Davis, Di Giuseppe \& Zezza (2017) stated that household size sometimes determines the food consumption of the household. The results, therefore, mean that the larger the household size, the more the household is likely to produce its food through subsistence farming. This may be because there is enough farm labour through family labour. However, subsistence production becomes necessary because it increases food availability in the household.

Education plays a crucial role in agriculture, as it determines the literacy rate. It makes it easy for an individual to acquire information from various sources. Education widens one's chances of being formally employed. When one is formally employed, they are unlikely to participate in agricultural activities. However, with that being said, education has a positive effect on 
subsistence farming in rural areas. The results reveal that years spent in school is significant at 5 per cent significance level. Sihlobo \& Nel (2016) also concur that education makes farming more innovative as there is technology that is being developed every day. The results estimate that the more the years a farmer spend in school increases, there greater is their involvement in subsistence farming in rural households.

Extension service tends to be inefficient in rural areas. Lyne, Jonas \& Ortmann (2018) defined extension service as the education aspect that is received by farmers. Rural households lack information and innovations in agriculture. Provision of proper extension services to rural people would result in better and improved agriculture in rural areas. The results indicate that extension service has a positive influence in subsistence farming in rural areas. Extension service has a positive coefficient and is significant at 5 per cent significance level. This simply means that a unit increase in extension service results in an increase in subsistence farming in rural areas.

Experience in farming encourages people to participate in agricultural activities. The more people participate in farming the more they see its benefits than purchasing everything from the markets. The results suggest that there was a positive relationship that exists between subsistence farming and farming experience. It is significant at 5 per cent significant level and has a positive coefficient. Mathebula (2015) stated that farming experience extends a zeal of farming in rural households and it assists in innovating new skills in the field.

Household income is directly proportional to own-food production. That means income and subsistence farming were positively related. The results show a positive coefficient of income and it was significant at 1 per cent significance level. People with high income were likely to be involved in agricultural activities since they can afford agricultural inputs. The results indicate that a unit increase in household income level results in an increase subsistence farming. Households with little or no reliable income are hesitant to invest the money they have in agriculture; they rather buy something to eat at the current moment. Mashamaite (2014) suggested that rural households must invest more in agriculture because income may not be enough to meet household expenditure.

Employment status negatively influences subsistence farming. The results indicate a negative coefficient and employment was significant at 5 per cent significance level. Households with employed heads were likely not to produce their food, they purchase from the market. Employed people have no time to participate in agricultural activities, they invest their time in their jobs. Unemployed individuals tend to take part in agricultural production because they believe it is cheaper than to buy from the markets. Mashamaite (2014) stated that most people in rural areas are unemployed and are dependent on social grants to have food on the table.

\section{CONCLUSION}

The study was investigating factors affecting subsistence farming in Nyandeni Local Municipality. The study results revealed that subsistence farming in the study area was practiced by male with an average age of 60 years and family size of 6 people per household. Farming was their main occupation as households in the study area were not working with $62 \%$. Subsistence farmers had a farm size of $2 \mathrm{Ha}$ which they were using to practice crop and vegetable farming with a farming experience of 10 years. Households were strictly practicing 
subsistence farming to provide food for home consumption and only sell surplus for income generation as to supplement their social grant securities. Subsistence farming in the study area was declining because majority of the farmers lack funding and knowledge, lack of water availability, lack of extension services and lack of farming equipment. The study concludes that subsistence farming is influenced by socio-economic factors such as age, sex, and family size, access to extension services, farming experience, employment, household income and education status. Therefore, the study recommends that policymakers and government must embark in education trainings which are aimed in increasing importance of farming in rural areas. The study further suggests that government and NGO extension personnel must be made available in rural areas so that they can disseminate farming information. The government must promote sustainable food production by ensuring collaboration of all stakeholders in government, private sector and NGOs or CBOs.

\section{References}

ALIBER, M. AND HART, T.G., 2009. Should subsistence agriculture be supported as a strategy to address rural food insecurity? Agr, 48(4): 434-458.

ALIBER, M. AND MDODA, L. 2015. The direct and indirect economic contribution of smallscale black agriculture in South Africa. Agrekon, 54: (2), 18-37.

AKINYEMI, B.E. AND MUSHUNJE, A. 2019. Land ownership and usage for agriculture: Empirical evidence from South African Living Conditions Survey, Cogent Social Sciences, 5 (1): 1663691. https://doi.org/10.1080/23311886.2019.1663691.

BAIPHETHI, M.N. AND JACOBS, P.T. 2009. The contribution of subsistence farming to food security in South Africa. Agr, 48(4): 459-482.

BEDEMO, A., GETNET, K., KASSA, B. AND CHAURASIA, S. 2013. Off-farm labor supply decision of adults in rural Ethiopia: Double hurdle approach. J. Agri. Eco. Dev., 2 (4): 154-165.

BHANDARI, P. AND GHIMIRE, D. 2016. Rural Agricultural Change and Individual Outmigration. Rur. Soc., 81 (4): 572-600.

DAVIS, B., DI GIUSEPPE, S. AND ZEZZA, A. 2017. Are African households (not) leaving agriculture? Patterns of households' income sources in rural Sub-Saharan Africa. Foo. Pol., 67: 153-174.

DEPARTMENT OF AGRICULTURE, FORESTRY, \& FISHERIES (DAFF). 2016. Economic Review of the South African Agriculture 2016/17.

DWESINI, N. E. 2015. The implications of smallholder agricultural productivity growth for poverty alleviation in post-apartheid South Africa. Published M. Dissertation, University of Fort Hare, RSA.

GOVENDER, L., PILLAY, K., SIWELA, M., MODI, A. AND MABHAUDHI, T. 2016. Food and Nutrition Insecurity in Selected Rural Communities of KwaZulu-Natal, South Africa—Linking Human Nutrition and Agriculture. Int. J. ENV. RES. Pub. Hea, 14(1): 17.

HEGER, M., ZENS, G. AND BANGALOR, M. 2018. Does the environment matter for poverty reduction? The role of soil fertility and vegetation vigor in poverty reduction. Washington DC: The World Bank.

KHAPAYI, M. AND CELLIERS, P.R. 2016. Factors limiting and preventing emerging farmers to progress to commercial agricultural farming in the King William's Town area of the Eastern Cape Province, South Africa. S. Afr. J. Agric. Ext., 44 (1):25 - 41.

KIBIRIGE, D. AND OBI, A. 2015. Agricultural efficiency of smallholder farmers in Eastern Cape Province of South Africa. Int. J. Eco. Com. Man., 3(9): 269-289. 
KIBIRIGE, D. 2013. The impact of human dimensions on smallholder farming in the Eastern Cape Province of South Africa. Published Thesis, University of Fort Hare, Alice, South Africa.

LILENSTEIN, K., WOOLARD, L. AND LEIBBRANDT, M. 2018. In-work poverty in South Africa: The impact of income sharing in the presence of high unemployment. In Handbook on in-work poverty. Edward Elgar Publishing. Accessed from https://www.elgaronline.com/downloadpdf/edcoll/9781784715625/9781784715625.0 0032.pdf Retrieved on 05 August 2020.

LYNE, M.C., JONAS, N. AND ORTMANN, G.F. 2018. A quantitative assessment of outsourced agricultural extension service in the Accessed from https://www.tandfonline.com/doi/abs/10.1080/1389224X.2017.1387159 on 04 August 2020.

MAKOFANE, M. AND GRAY, M. 2014. Factors hindering the successful outcome of rural community projects. Soc. Wor/Maa. Wer. 43 (3).

MASHAMAITE, K.A. 2014. The Contributions of Smallholder Subsistence Agriculture towards Rural Household Food Security in Maroteng Village, Limpopo Province. Published M. Dissertation, University of Limpopo, RSA.

MASUKU, M. SELEPE, M. AND NGCOBO, N. 2017. Small Scale Agriculture in Enhancing Household Food Security in Rural Areas. J Hum Ecol, 58 (3): 153-161. DOI: 10.1080/09709274.2017.1317504.

MATHEBULA, J., MOLOKOMME, M., JONAS, S. AND NHEMACHENA, C. 2017. Estimation of household income diversification in South Africa: A case study of three provinces. SA J. Sci., 113 (1/2): 1-9.

MATHEBULA, J.H. 2015. Determinants of household participation in agricultural production in Shatale region of the Bushbuckridge local municipality, Mpumalanga Province. Published M. Dissertation, University of Limpopo, RSA.

MAZIBUKO, N. V. E. AND ANTWI, M. A. 2019. Socio-Economic Factors Influencing Smallholder Farmers Agricultural Infrastructure Availability, Accessibility and Satisfaction: A Case on North West Province in South Africa. OIDA Int. J. Sus. Dev., 12 (5): 11-26.

MEHRARA, M. AND BAGHBANPOUR, J. 2016. The Contribution of Industry and Agriculture Exports to Economic Growth: The Case of Developing Countries. Wor. Sci. New., 46: 100-111.

MEYER, D.F. AND NISHIMWE-NIYIMBANIRA, R. 2016. The impact of household size on poverty: An analysis of various low-income townships in the Northern Free State region, South Africa. Afri. Pop. Stud., 30 (2).

MOTHAE, T.J. 2017. Assessment of communal land rights for smallholder farmers' access to markets in South Africa: Implications on gender (Doctoral dissertation, University of KwaZulu-Natal).

MTERO, F. 2017. Rural livelihoods, large-scale mining and agrarian change in Mapela, Limpopo, South Africa. Res. Pol., 53: 190-200. Accessed from https://www.sciencedirect.com/science/article/pii/S0301420716303221 on 02 August 2020.

MUGAMBIWA, S.S. AND TIRIVANGASI, H.M. 2017. Climate change: A threat towards achieving 'Sustainable Development Goal number two'(end hunger, achieve food security and improved nutrition and promote sustainable agriculture) in South Africa. Jàmbá: J. Dis. Risk Stu, 9(1): 1-6. 
MYENI, L., MOELETSI, M., THAVHANA, M., RANDELA, M. AND MOKOENA, L. 2019. Barriers Affecting Sustainable Agricultural Productivity of Smallholder Farmers in the Eastern Free State of South Africa. Sus. 11, 3003; DOI: 10.3390/su11113003.

NDABENI, L.L. 2016. An analysis of rural-urban linkages and their implications for policies that sustain development in a space continuum. Accessed from https://www.researchgate.net/profile/Chee_Hung_Foo4/post/Has_anyone_done_resea rch on the ruralurban_linkages/attachment/59d62f3779197b807798d5de/AS:357452013948928@ 146 2234609974/download/ANALYSIS+OF+RURALURBAN+LINKAGES+AND+THEIR+IMPLICATIONS.pdf on 27 August 2017.

NETHENGWE, N.S., UHUNAMURE, S. E. AND TINARWO, D. 2018. Potentials of biogas as a source of renewable energy: A case study of South Africa. Inte. J. Ren. Ene. Res., 8(2): 1112-1123. Accessed from https://www.researchgate.net/profile/David_Tinarwo/publication/326235863_Potentia 1s_of_biogas_as_a_source_of_renewable_energy_A_case_study_of_South_Africa/lin $\mathrm{ks} / 5 \mathrm{e} 074 \mathrm{~d} 96 \mathrm{a} 6 \mathrm{fdcc} 283743 \mathrm{~b} 7 \mathrm{fb} /$ Potentials-of-biogas-as-a-source-of-renewableenergy-A-case-study-of-South-Africa.pdf. on o6 August 2020.

NKONYA, E., GERBER, N. AND BAUMGARTNER, P. 2012. The economics of land degradation toward an integrated global assessment. Dev. Eco. Pol., 66: 443-516.

POULSEN, M. N., MCNAB, P. R., CLAYTON, M. L. AND NEFF, R. A. 2015. A systematic review of urban agriculture and food security impacts in low-income countries. Foo. Pol., 55: 131-146.

SAQIB, S.E, KUWORNU, J. K. M., PANEZIA, S. AND ALI, U. 2018. Factors determining subsistence farmers' access to agricultural credit in flood-prone areas of Pakistan. Kas. J. Soc. Sci., 39: 262-268.

SERTOGLU, K., UGURAL, S. AND BEKUN, F.V. 2017. The contribution of the agricultural sector on the economic growth of Nigeria. Int. J. Eco. Fin. Iss., 7(1): 547-552.

SEWELL, S.J. \& DESAI, S. 2016. The Impacts of Undeveloped Roads on the Livelihoods of Rural Women. Rev. Soc. Sci., 1(8): 15-29. Mathebula (2015

SIBHATU, K.T. AND QAIM, M. 2017. Rural food security, subsistence agriculture, and seasonality. PLoS ONE 12(10): e0186406. Accessed from https://doi.org/10.1371/journal.pone.0186406 on 06 August 2020.

SIHLOBO, W. AND NEL, L. 2016. Is South Africa's agricultural sector addressing inclusive socio-economic development? Opp. Chan., 68: 65.

STATISTICS SOUTH AFRICA (Stats SA). 2015. South Africa: Literacy rate from 2007 to 2015, total and by gender. The statistic portal. Accessed from https://www.statista.com/statistics/572836/literacy-rate-in-south-africa/ $\quad$ on 13 September 2018.

TIBESIGWA, B. AND VISSER, M. 2016. Assessing gender inequality in food security among small-holder farm households in urban and rural South Africa. Wor. Dev., 88: 33-49.

VAN AVERBEKE, W. AND KHOSA, T.B. 2007. The contribution of smallholder subsistence agriculture to the nutrition of rural households in semi-arid environment in South Africa. W. SA, 33(3): 413-418.

WALSH, C.M. AND VAN ROOYEN, F.C. 2015. Household food security and hunger in rural and urban communities in the Free State Province, South Africa. Ecology of food and nutrition, 54(2): 118-137.

WORLD BANK. 2018. Unlocking the Potential of Agriculture for Afghanistan's Growth; World Bank: Washington, DC, USA. Accessed from 
www.worldbank.org/en/country/afghanistan/publication/unlocking-potentialofagriculture-for afghanistan-growth on 6 August 2020.

YOU, L., RINGLER, C., NELSON, G., WOOD-SICHRA, U., ROBERTSON, R. AND WOOD, S. 2010. What is the irrigation potential for Africa? A combined biophysical and socioeconomic approach. IFPRI Discussion Paper 00993. Washington, DC. International Food Policy Research Institute (IFPRI). 
S. Afr. J. Agric. Ext.

Vol. 48 No.2, 2020: 92 - 105

http://dx.doi.org/10.17159/2413-3221/2020/v48n2a540
Siphesihle \& Lelethu

(License: CC BY 4.0) 